\section{$\underset{\substack{\text { hommes } \\ \text { \& migrations }}}{ }$}

\section{Hommes \& migrations}

Revue française de référence sur les dynamiques

migratoires

\section{$1279 \mid 2009$}

L'Afrique en mouvement

\title{
Un si beau voyage
}

Film franco-tunisien de Khaled Ghorbal

\section{André Videau}

\section{(2) OpenEdition \\ 1 Journals}

Édition électronique

URL : http://journals.openedition.org/hommesmigrations/354

DOI : $10.4000 /$ hommesmigrations.354

ISSN : 2262-3353

Éditeur

Musée national de l'histoire de l'immigration

\section{Édition imprimée}

Date de publication : 1 mai 2009

Pagination : 198

ISSN : 1142-852X

\section{Référence électronique}

André Videau, « Un si beau voyage », Hommes \& migrations [En ligne], 1279 | 2009, mis en ligne le 29 mai 2013, consulté le 22 septembre 2020. URL : http://journals.openedition.org/hommesmigrations/ 354 ; DOI : https://doi.org/10.4000/hommesmigrations.354

Ce document a été généré automatiquement le 22 septembre 2020.

Tous droits réservés 


\title{
Un si beau voyage
}

\author{
Film franco-tunisien de Khaled Ghorbal
}

\section{André Videau}

1 Même pour ses jeunes copains et compatriotes Mansour et Karim (Aboubacar Eros Sissoko et Abdelhafid Metalsi), Mohamed, travailleur retraité tunisien, garde une part de mystère. Depuis des années, il n'a pas quitté le foyer où il a son logement et ses habitudes. Toujours tiré à quatre épingles (ah! l'art de lessiver les chemises dans un lavabo et de les faire sécher sans un pli !), c'est un chic type, qui ne refuse jamais de donner un coup de main ou de prodiguer un conseil, ou de partager un bon petit gueuleton. Ses pieux camarades respectent l'autorité, le savoir et le prestige de l'ancien, même quand il les convie à boire un coup et remplace le couscous par la paella (dont il sert délicatement à part l'indispensable chorizo). De sa vie sentimentale, on ne sait rien. Ou pas grand-chose. Une liaison, douloureusement interrompue avec Pilar, "l'Espagnole" (Assumpta Serna), quelques visites furtives aux prostituées.

2 Et puis cette apparente sérénité va basculer devant le diagnostic sans appel du médecin consulté à l'hôpital Avicennes. Jusque-là, il avait refusé de prendre au sérieux une douleur lancinante dans la poitrine. La vie change de couleur. Le monde rétrécit et enlaidit. "Et si vous alliez faire un petit séjour au bled?" conseille sans illusion la cardiologue. Contre toute attente, Mohamed accepte. Il prend même une décision radicale. Son retour sera définitif. Il rend une visite d'adieu à Pilar qui a refait sa vie. Malgré la tendresse encore vive, il y des blessures dont on ne guérit pas.

3 Pour partir plus léger, il partage ses modestes biens entre ses deux amis. Voilà totalement effacée la parenthèse de l'émigration. Il n'a fait place nette que pour le vide. L'accueil du pays natal, après dix-sept ans d'absence, le désespère davantage. Les gens sont sournois, avides, indifférents. Et s'il poursuivait l'ascèse en marchant dans le désert? Le vent et le sable effaceront les traces de ce si beau voyage sans retour.

4 Ce film austère est sans doute une allégorie de l'immigration. Sa revendication de la liberté jusqu'à l'extrême du suicide ne manque pas de noblesse, mais c'est par la présence fulgurante et fragile de Farid Chopel qu'il nous touche le plus. L'acteur allait mourir quelques semaines après la fin du tournage. Il avait déjà ce profil glabre, ce visage émacié, cette silhouette dégingandée. Remercions l'auteur de lui avoir fourni son 
plus beau rôle, au terme d'une carrière trop courte et chaotique, et souvenons nous de ce Buster Keaton, impavide et mutique, capable, avec son complice Ged Marlon, de déchaîner Les aviateurs dans une cascade de rire. ${ }^{1}$

\section{NOTES}

1. Spectacle burlesque donné en 1982, où le duo de comédiens mettait en boite le cinéma américain aéronautique. 